\section{Elevation of cytokines during open heart surgery with cardiopulmonary bypass: participation of interleukin 8 and 6 in reperfusion injury}

Takae Kawamura,* Reiji Wakusawa,* Kazutoshi Okada,* Shoya Inada $†$

\begin{abstract}
Myocardial ischaemia is one of the major causes of low output syndrome during open heart surgery. Injury associated with ischaemia and reperfusion has been considered to result, in part, from the action of neutrophils, the interaction of neutrophils with vascular endothelial cells, and the effects of cytokines which are mediators that induce and modify reactions between these substances. We investigated cell injury in relation to the concentrations of interleukins 6 and $8(I L-6$ and $I L-8)$, which have recently received attention as neutrophil activators. Neutrophil counts, granulocyte elastase (GEL), $I L-6, I L-8$, tumour necrosis factor- $\alpha(T N F-\alpha), C K$, and $C K-M B$ concentrations were determined serially in 11 patients undergoing open heart surgery with cardiopulmonary bypass (CPB). Neutrophil counts (mean $\pm S D 2717 \pm 2421 \mathrm{\mu l}^{-1}$ preoperatively) peaked $60 \mathrm{~min}$ after declamping the aorta at $7432 \pm 4357 \mu l^{-1}(P<0.01)$ and remained elevated $7136 \pm 5194 \mu l^{-1}$ at $180 \min (P<0.01)$. Plasma GEL level (168 $\pm 71 \mu \mathrm{g} \cdot L^{-1}$ preoperatively) peaked at $1134 \pm 453 \mu \mathrm{g} \cdot L^{-1} 120 \mathrm{~min}$ after declamping of the aorta $(P<0.01)$ and remained elevated, $1062 \pm 467 \mu \mathrm{g} \cdot L^{-1}$, after $180 \min (P<0.01)$. Serum $I L-6$ level $\left(118 \pm 59 \mathrm{pg} \cdot \mathrm{ml}^{-1}\right.$ preoperatively) peaked at $436 \pm 143 \mathrm{pg} \cdot \mathrm{ml}^{-1} 60 \mathrm{~min}$ after declamping of the aorta $(P<0.01)$ and remained elevated, $332 \pm 109 \mathrm{pg} \cdot \mathrm{ml}^{-1}$, after $180 \mathrm{~min}$. Serum $\mathrm{IL}-8$ level $(37 \pm$ $44 \mathrm{pg} \cdot \mathrm{ml} \mathrm{l}^{-1}$ preoperatively) peaked at $169 \pm 86 \mathrm{pg} \cdot \mathrm{ml}^{-1}$ at 60 min after declamping of the aorta $(P<0.001)$ and remained
\end{abstract}

Key words

HEART: ischaemia;

HORMONES: cytokines, interleukins.

From the *Department of Anesthesiology, Iwate Medical University 19-1, Uchimaru, Morioka, Japan, and the †Department of Microbiology, Iwate Medical University. Address correspondence to: Dr. Kawamura. Accepted for publication 21st July, 1993. elevated at $113 \pm 78 \mathrm{pg} \cdot \mathrm{ml}^{-1} 180$ min after declamping of the aorta. Serum TNF- $\alpha$ was decreased at $60 \mathrm{~min}$ after aortic occlusion but otherwise did not change. Plasma GEL concentrations correlated with serum $I L-8$ levels $(R=0.7, P=0.001)$ and the IL-6 and IL-8 concentrations correlated with the duration of aortic clamping $(R=0.64, P=0.01, R=0.7, P$ $=0.01)$. We conclude that the increases of $I L-6$ and $I L-8$ occur as a result of ischaemia, and suggest that these cytokines participate in reperfusion injury by activating neutrophils.

Lischémie myocardique est une des principales causes du syndrome de bas débit pendant la chirurgie à coeur ouvert. On pense que la lésion associée à lïschémie et la reperfusion résulte en partie de laction des neutrophiles, linteraction des neutrophiles avec les cellules vasculaires endothéliales et l'activité de médiateurs, les cytokines qui induisent et modifient les réactions entre ces substances. Nous avons examiné la relation de la lésion cellulaire avec la concentration des interleukines 6 et 8 (IL6 et IL-8), qui ont récemment attiré l'attention comme activateurs de neutrophiles. Chez II patients soumis à une chirurgie cardiaque ouverte avec circulation extracorporelle (CEC), on mesure en série le décompte des neutrophiles, l'élastase gramulocytaire (GEL), IIL-6 et l'IL-8, le facteur- $\alpha$ de nécrose tumorale $(T N F-\alpha)$ et la concentration des $C K$ et $C K-M B$. Le décompte des neutrophiles (moyenne $\pm S D: 2717 \pm 2421 \mu l^{-1}$ en préopératoire) atteint un maximum de $7432 \pm 435 \mu l^{-1}$ 60 min après le déclampage de laorte $(P<0,01)$ et demeure élevé, $7136 \pm 5194 \mu^{-1}$, à $180 \min (P<0,01)$. Le niveau de la GEL plasmatique (168 $\pm 71 \mu \mathrm{g} \cdot \mathrm{L}^{-1}$ en préopératoire) atteint un maximum de $1134 \pm 453 \mu \mathrm{g} \cdot \mathrm{L}^{-1}$ après $120 \mathrm{~min}$ du déclampage de l'aorte $(P<0,01)$ et demeure élevé, 1062 $\pm 467 \mu \mathrm{g} \cdot L^{-1}$ après $180 \mathrm{~min}$ de déclampage $(P<0,01)$. L' $1 L$ 6 sérique $\left(118 \pm 59 \mathrm{pg} \cdot \mathrm{ml}^{-1}\right)$ atteint un maximum de 436 $\pm 143 \mathrm{pg} \cdot \mathrm{ml}^{-1} 60$ minutes après le déclampage de l'aorte $(P$ $<0,01)$ et demeure élevé, $332 \pm 109 \mathrm{pg} \cdot \mathrm{ml}^{-1}$ après $180 \mathrm{~min}$. Le niveau sérique d'IL-8 (37 $\pm 44 \mathrm{pg} \cdot \mathrm{ml}^{-1}$ en préopératoire) 
atteint un maximum de $169 \pm 86 \mathrm{pg} \cdot \mathrm{ml}^{-1} 60$ min après le déclampage de l'aorte $(P<0,01)$ et demeure élevé, $113 \pm 78$ $\mathrm{pg} \cdot \mathrm{ml}^{-1}$ après $180 \mathrm{~min}$. Le TNF- $\alpha$ décrôt $60 \mathrm{~min}$ après le clampage aortique mais ne change plus par la suite. La concentration plasmatique de GEL est en corrélation avec le niveau sérique de l'lL-8 ( $R=0,7, P=0,001)$. Les concentrations d'L-6 et d'IL-8 sont en corrélation avec la durée du clampage ( $R=0,64, P=0,01, R=0,07, P=0,01$ ). Nous concluons que les augmentations d'IL-6 et d'IL-8 résultent de lischémie et nous suggérons qu'en activant les neutrophiles, ces cytokines participent à la genèse de la lésion de reperfusion.

Since it was reported that infarct size could be reduced by suppressing leukocyte infiltration into the ischaemic myocardium with anti-leukocyte antibodies ${ }^{1}$ and nonsteroidal anti-inflammatory agents, ${ }^{2}$ attention has been focused on the role of leukocytes in progressive ischaemic myocardial damage and reperfusion injury. The mechanism of local leukocyte infiltration is complicated. The substances C5a, leukotriene B4 and various cytokines are known as endogenous leukocyte chemotactic factors which finally guide leukocytes to the target site of action. Also, tumour necrosis factor- $\alpha$ (TNF- $\alpha$ ), IL-6, and IL8 have been reported to be involved in tissue injury but detailed studies of their action in relation to reperfusion injuries have not been performed. Accordingly, in an attempt to clarify their participation in reperfusion injury, we examined the changes in circulating concentrations of these cytokines in relation to leukocyte count, creatine phosphokinase (CK), CK-MB and granulocyte elastase (GEL) in patients during CPB.

\section{Methods}

With institutional approval and informed consent, we studied 11 patients who underwent open heart surgery (Table I).

Preanaesthetic medications included diazepam (0.2 $\left.\mathrm{mg} \cdot \mathrm{kg}^{-1}\right)$, hydroxyzine (1 $\left.\mathrm{mg} \cdot \mathrm{kg}^{-1}\right)$, dumeor (1 $\left.\mathrm{mg} \cdot \mathrm{kg}^{-1}\right)$ and atropine $\left(0.01 \mathrm{mg} \cdot \mathrm{kg}^{-1}\right)$. Anaesthesia was induced with fentanyl $\left(30 \mu \mathrm{g} \cdot \mathrm{kg}^{-1}\right)$, and tracheal intubation was facilitated with vecuronium $\left(0.15 \mathrm{mg} \cdot \mathrm{kg}^{-1}\right)$. Anaesthesia was maintained using oxygen, and high-dose fentanyl (total $100 \mu \mathrm{g} \cdot \mathrm{kg}^{-1}$ ). Ventilation was controlled to maintain $\mathrm{PaCO}_{2}$ at approximately $40 \mathrm{mmHg}$.

The perfusion apparatus included a Hollow fibre membrane oxygenator (Terumo, Capiox) and nonpalsatile roller pump (Pemco Inc). A mixture of $20 \%$ mannitol, $7 \%$ sodium bicarbonate, electrolyte solution, and CPDadded preserved blood was primed, and then perfused at a flow rate of $2.4 \mathrm{~L} \cdot \mathrm{m}^{-2} \cdot \mathrm{min}^{-1}$. Haematocrit levels were maintained at $25 \%$ or more throughout CPB. Crystaloid cardioplegia was used for cardiac preservation.
The ECG, EEG, and oesophageal and rectal temperatures were monitored continuously. Arterial blood oxygen saturation was also monitored continuously with a pulse-oximeter (Datex, Satlite), and end-tidal carbon dioxide concentrations with capnography (Datex, Capnomac). A catheter was placed in the radial artery to measure arterial pressure directly, and from which blood samples were drawn. Six blood samples were drawn after inducing anaesthesia, at the following times: before operation, immediately before starting CPB, $60 \mathrm{~min}$ after aortic occlusion, and 60,120 and $180 \mathrm{~min}$ after declamping the aorta. In each sample, CK, CK-MB, peripheral WBC, neutrocyte, GEL, IL-6, IL-8, and TNF- $\alpha$ concentrations were measured. The IL-8, IL-6 and TNF$\alpha$ were measured by ELISA kits (IL-8: R \& D systems, Minneapolis, MN, USA ${ }^{3}$ IL-6: Toray Fujibionics Inc, Tokyo, Japan, ${ }^{4}$ TNF- $\alpha$ : Medgenix Diagnostics, Belgium) and GEL by enzyme linked immunosorbent assay as GEL- $\alpha_{1}-\mathrm{PI}$ complex. Data were analyzed by analysis of variance and Neuman-Keuls multiple comparison tests. Significant difference was defined as $\mathbf{P}<0.05$. All data are expressed as the mean $\pm \mathrm{SD}$.

\section{Results}

The patient's age, body weight, ejection fraction, cardiopulmonary bypass time, aortic clamp time and cardioplegic solution are shown in Table I. The mean serum $\mathrm{CK}$ and $\mathrm{CK}-\mathrm{MB}$ concentrations increased at $60 \mathrm{~min}$ after declamping of the aorta compared with those before operation and $60 \mathrm{~min}$ after aortic occlusion and increased continuously until $180 \mathrm{~min}$ after declamping of the aorta $(P<0.01$, Table II).

The polymorphonuclear leukocyte (PMN) count increased from $60 \mathrm{~min}$ after declamping of the aorta compared with that before operation and $60 \mathrm{~min}$ after aortic occlusion and remained elevated at $180 \mathrm{~min}$ after declamping of the aorta $(P<0.01$, Table II).

The plasma granulocyte elastase concentration was increased $60 \mathrm{~min}$ after declamping of the aorta compared with that before operation and $60 \mathrm{~min}$ after aortic occlusion and high levels were maintained $180 \mathrm{~min}$ after declamping of the aorta $(P<0.01$, Figure 1$)$.

Serum IL- 8 and IL-6 concentrations increased $60 \mathrm{~min}$ after declamping of the aorta and remained high at 180 min after declamping of the aorta $(P<0.001$, Figures 2 and 3). Furthermore, the concentrations of IL-8 at 60, $120,180 \mathrm{~min}$ after declamping of the aorta were higher than at $60 \mathrm{~min}$ after aortic occlusion $(P<0.001$, Figure 2) and the serum IL-6 concentration at $60 \mathrm{~min}$ after declamping of the aorta was higher than that $60 \mathrm{~min}$ after aortic occlusion ( $P<0.001$, Figure 3 ).

TNF- $\alpha$ was decreased at $60 \mathrm{~min}$ after aortic occlusion but otherwise did not change (Table II). 
TABLE 1 Characteristics of patients and results (mean \pm SD)

\begin{tabular}{|c|c|c|c|c|c|c|c|c|}
\hline Patient & $\begin{array}{l}\text { Age } \\
\text { (y) }\end{array}$ & $\begin{array}{l}\text { Weight } \\
(k g)\end{array}$ & Diagnasis & $\begin{array}{l}E F \\
(\%)\end{array}$ & $\begin{array}{l}C P B \\
(\min )\end{array}$ & $\begin{array}{l}\text { Ao.-clamp } \\
\text { (min) }\end{array}$ & $\begin{array}{l}\text { L.-temp } \\
(\mathrm{C})\end{array}$ & $\begin{array}{l}\text { C.-plegia } \\
\text { (ml) }\end{array}$ \\
\hline 1 & 71 & 37 & AS & 64 & 180 & 120 & 28.9 & 2050 \\
\hline 2 & 66 & 53 & AR & 72 & 184 & 85 & 29.4 & 2100 \\
\hline 3 & 55 & 68 & AP & 56 & 115 & 63 & 30 & 1700 \\
\hline 4 & 63 & 51 & AR & 35 & 260 & 140 & 27.9 & 2800 \\
\hline 5 & 66 & 54 & AR & 50 & 190 & 109 & 27.8 & 1800 \\
\hline 6 & 24 & 45 & VSD, PH & 68 & 135 & 79 & 29.9 & 1640 \\
\hline 7 & 66 & 41 & $\mathrm{AP}$ & 58 & 180 & 58 & 28 & 1200 \\
\hline 8 & 47 & 48 & AR, MS & 52 & 180 & 80 & 28 & 1640 \\
\hline 9 & 47 & 72 & AR & 68 & 170 & 120 & 28.2 & 3100 \\
\hline 10 & 70 & 40 & AP & 68 & 240 & 43 & 25.7 & 2300 \\
\hline 11 & 61 & 65.5 & MS & 52 & 160 & 60 & 29.3 & 1600 \\
\hline Mean & 58 & 52 & & 58 & 181 & 87 & 28.4 & 1993 \\
\hline SD & 13 & 11 & & 10 & 41 & 31 & 1.2 & 560 \\
\hline
\end{tabular}

AS: aortic stenosis; AR: aortic regurgitation; AP: angina pectoris; VSD: ventricular septal defect; PH: pulmonary hypertension; MS: mitral stenosis; EF: ejection fraction; CPB: cardiopulmonary bypass; AO-clamp: aortic clamp time; L-temp.: lowest temperature; C-plegia.: cardioplegia.

TABLE II Concentrations of serum creatine phosphokinase (CK), CK-MB, polymorphonuclear leukocyte (PMN) and serum tumor necrosis factor- $\alpha$ (TNF- $\alpha$ ) in each period.

\begin{tabular}{lcccccc}
\hline & $I$ & 2 & 3 & 4 & 5 & 6 \\
\hline CK $\left(\mathrm{IU} \cdot \mathrm{L}^{-1}\right)$ & $161 \pm 116$ & $229 \pm 124$ & $246 \pm 73$ & $428 \pm 130^{*} \dagger$ & $519 \pm 240^{*} \dagger$ & $592 \pm 179^{*} \dagger$ \\
$\mathrm{CK}-\mathrm{MB}\left(\mathrm{lU} \cdot \mathrm{L}^{-1}\right)$ & $0.5 \pm 0.7$ & $0.7 \pm 0.9$ & $0.7 \pm 1.1$ & $4.1 \pm 3.2^{* \dagger}$ & $6.9 \pm 3.2^{* \dagger}$ & $10.9 \pm 6.8^{*} \dagger$ \\
$\mathrm{PMN}\left(\mu \mathrm{I}^{-1}\right)$ & $2717 \pm 2421$ & $3257 \pm 2181$ & $3016 \pm 1786$ & $7432 \pm 4357^{* \dagger}$ & $7192 \pm 4829^{*} \dagger$ & $7136 \pm 5194^{*} \dagger$ \\
TNF- $\alpha\left(\mathrm{pg} \cdot \mathrm{mL}^{-1}\right)$ & $11.4 \pm 15$ & $10.9 \pm 12$ & $5.7 \pm 6^{*}$ & $6.9 \pm 8$ & $9.8 \pm 9$ & $6.9 \pm 7$ \\
\hline
\end{tabular}

$* P<0.01$ versus before operation (1).

$\dagger P<0.01$ versus $60 \mathrm{~min}$ after aortic occlusion (3).

Sampling point (1) before operation; (2) pre-CPB; (3) $60 \mathrm{~min}$ after aortic clamp; (4) $60 \mathrm{~min}$ after declamping of the aorta; (5) $120 \mathrm{~min}$ after declamping of the aorta; (6) $180 \mathrm{~min}$ after declamping of the aorta.

Regression analysis demonstrated a relationship between GEL and IL-8 ( $R=0.7, P=0.001$, Figure 4), and between GEL and CK-MB (R $=0.47, P=0.02$, Figure 5).

Correlations were obtained between IL-8 and aortic clamping time $(\mathrm{R}=0.7, P=0.01$, Figure 6$)$, and between IL-6 and aortic clamping time $(\mathrm{R}=0.64, P=0.01$, Figure 7). No correlation was found between IL-8 and IL-6.

Correlations were observed between IL- 6 and CK-MB $(\mathrm{R}=0.62, P=0.002$, Figure 8$)$ and between IL-8 and CK-MB (R $=0.64, P=0.001$, Figure 9).

No correlation was found between IL-6 and GEL nor between TNF- $\alpha$ and GEL.

\section{Discussion}

Many studies have shown that cardiac infarct size was decreased in reperfusion models when neutrophil infiltration was suppressed. ${ }^{1,2,5}$ As a result, attention has focused on the possible role of neutrophils in reperfusion injury. Our study demonstrated an increase in CK, CK$\mathrm{MB}$, neutrophils and GEL from $60 \mathrm{~min}$ after declamping

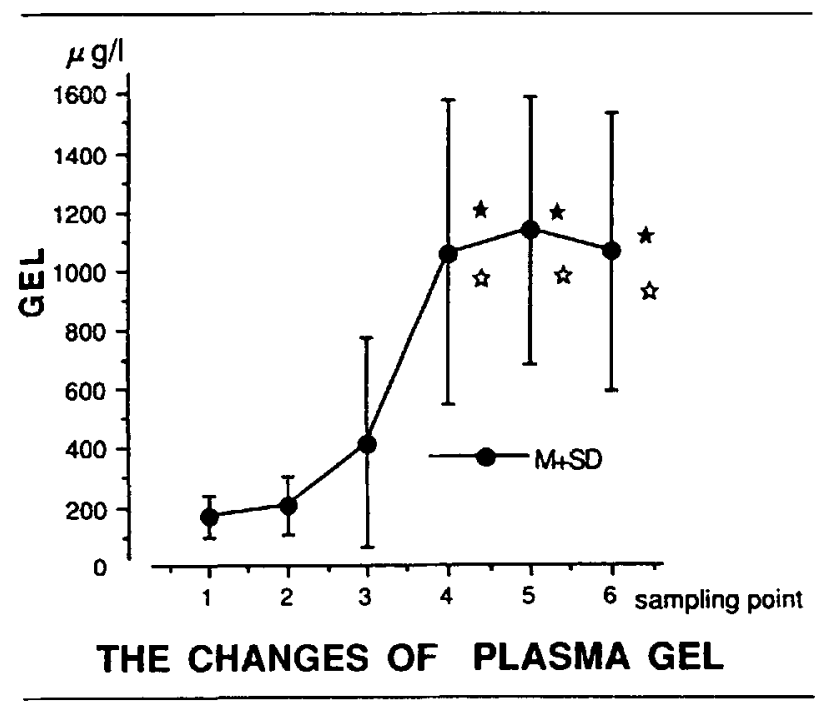

FIGURE 1 Absolute levels of plasma granulocyte elastase level in each period. $\star P<0.01$ versus before operation (1). $\$ P<0.01$ versus $60 \mathrm{~min}$ after aortic occlusion (3). Sampling point (1) before operation; (2) pre-CPB; (3) 60 min after aortic ooclusion; (4) $60 \mathrm{~min}$ after declamping of the aorta; (5) $120 \mathrm{~min}$ after declamping of the aorta; (6) 180 min after declamping of the aorta. 


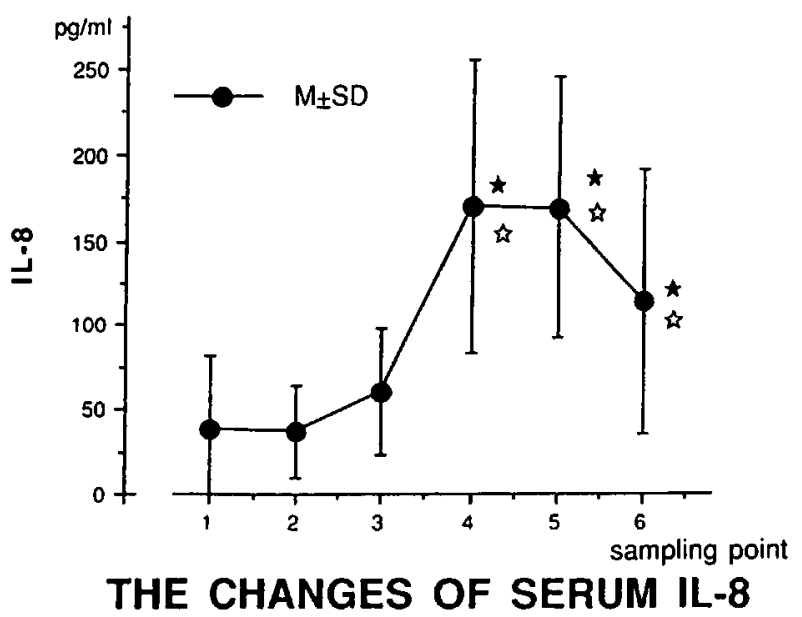

FIGURE 2 Absolute levels of serum interleukin-8 concentration in each period. $\star P<0.001$ versus before operation (1). $\star P<0.001$ versus $60 \mathrm{~min}$ after aortic occlusion (3).

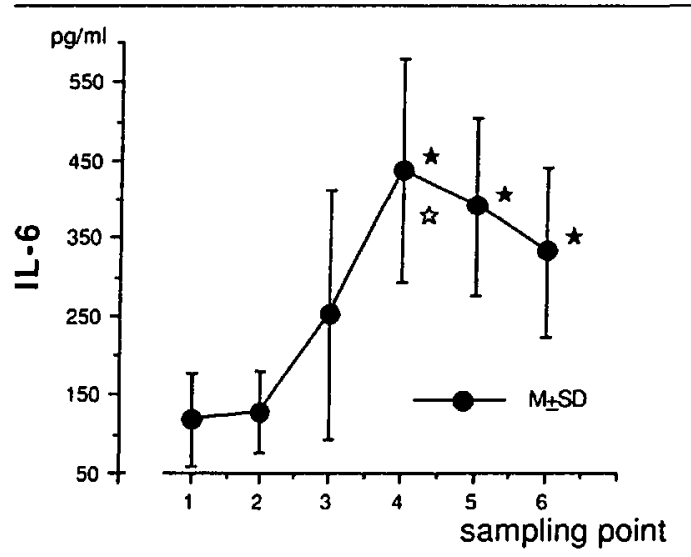

THE CHANGES OF SERUM IL-6

FIGURE 3 Absolute levels of serum interleukin- 6 concentration in each period. $\star P<0.001$ versus before operation. $\$ P<0.001$ versus $60 \mathrm{~min}$ after aortic occlusion (3).

of the aorta which suggests that neutrophils participate in reperfusion injury.

Before leukocytes infiltrate into tissues, appropriate cell adhesion molecules ${ }^{6}$ should be expressed first on the surface of the leukocytes, and endotherial cells and then the leukocytes should adhere to the vascular endothelial cells, penetrate them, and then destroy their basal membrane, followed by migration to the target site of action. Interleukin 8 is a factor which may finally guide leukocytes to the target site of action. It has been shown, in vitro, to be neutrophil chemotactic and, in addition, it is known to have other biological actions including neutrophil activation. Activated neutrophils induce the release of lysosomes ${ }^{7,8}$ and the production of leukotriene

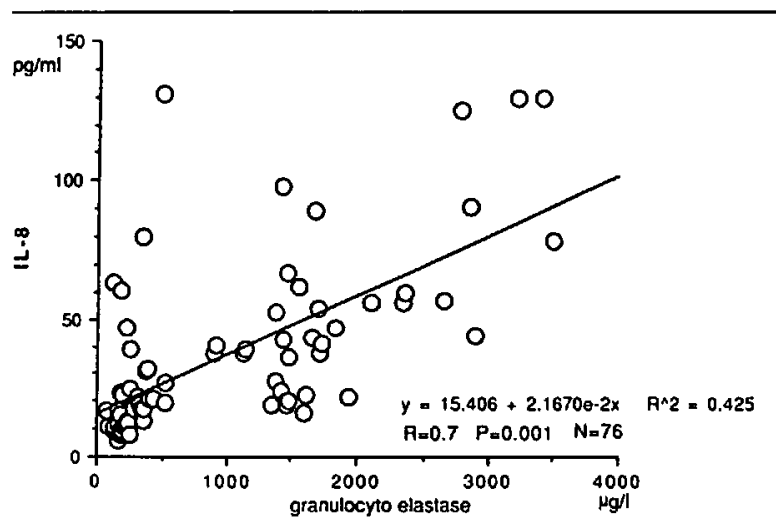

CORRELATION BETWEEN PLASMA GEL AND SERUM IL-8

FIGURE 4 Relationship between absolute values in granulocyte elastase and interleukin- $8(\mathrm{R}=0.7, P=0.001)$.

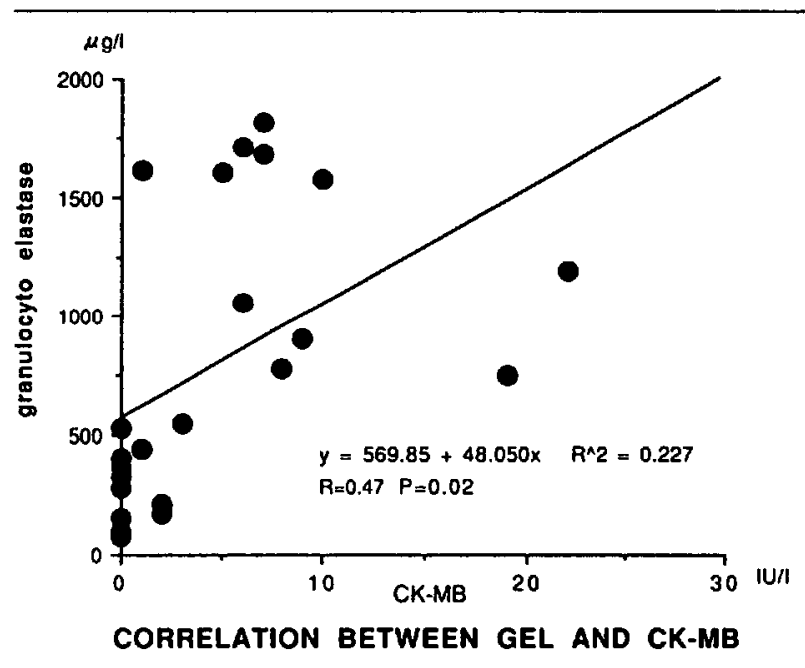

FIGURE 5 Relationship between absolute values in granulocyte elastase and CK-MB $(\mathrm{R}=0.47, P=0.02)$.

B4. ${ }^{9}$ They also augment the expression of CR-1 and Mac-1 which are involved in cell adhesion, and promote the adhesion of neutrophils to unstimulated vascular endothelial cells. ${ }^{10,11}$

The present study showed an increase in IL- 8 as well as in neutrophils and GEL concentrations. In addition, IL-8 was positively correlated with GEL. This observation suggests that GEL was released from neutrophils activated by IL- 8 , and the cells were injured. The results are consistent with those presented by Endo et al. ${ }^{12}$ who reported that IL-8 was correlated with GEL in septic ARDS, indicating that IL-8 was closely involved in the production and release of GEL. IL-8 is produced from monocytes, macrophages, fibroblasts and vascular endothelial cells following stimulation with TNF and IL$1 .{ }^{13-15}$ There is also a recent report that IL-8 is produced 


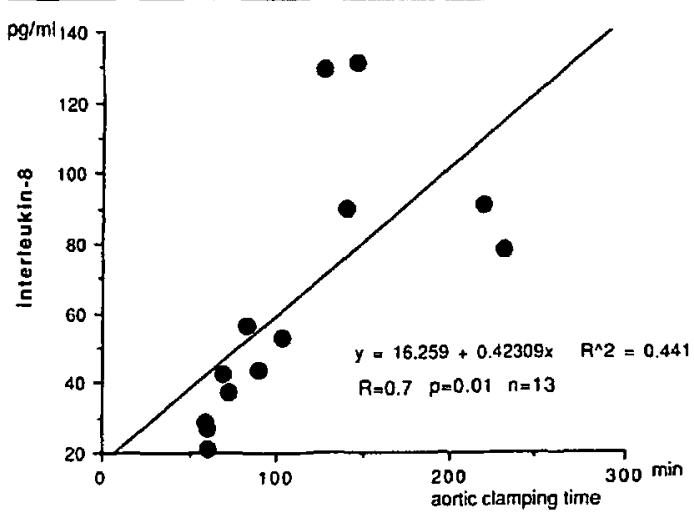

CORAELATION BETWEEN IL-8 AND AORTIC CLAMPING TIME

FIGURE 6 Relationship between absolute values in interleukin- 8 and aortic occlusion time $(\mathrm{R}=0.7, P=0.01)$.

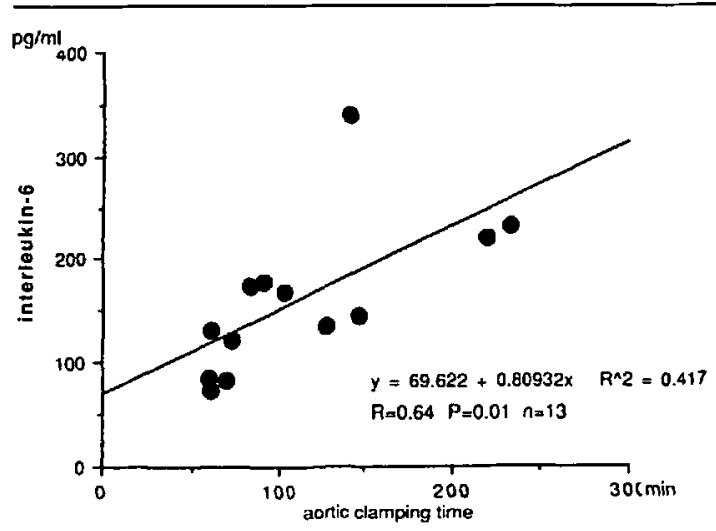

CORRELATION BETWEEN IL-6 AND AORTIC CLAMPING TIME

FIGURE 7 Relationship between absolute values in interleukin- 6 and aortic occlusion time $(\mathrm{R}=0.64, P=0.01)$.

in tissue hypoxia associated with ischaemia. ${ }^{16}$ In our study, TNF- $\alpha$ did not increase and positive correlation between IL- 8 and aortic clamping time was observed, suggesting that IL-8 production increased in ischaemia but was not stimulated with TNF- $\alpha$. Reperfusion injury may develop by the pathway starting from ischaemia $\rightarrow$ increased production of IL-8 $\rightarrow$ activation of neutrophils $\rightarrow$ release of GEL $\rightarrow$ cell injury.

Interleuken- 6 is produced from $T$ cells, B cells, macrophages and other immunocomponent cells. ${ }^{17,18}$ It plays an important role not only in the immune reaction, but also in acute phase reaction and the defence mechanism. ${ }^{19}$ TNF- $\alpha$ has also been reported to be involved in tissue injury in a similar fashion to IL-1 and IL-8. Our study showed that IL-6, like IL-8, increased from $60 \mathrm{~min}$ after declamping of the aorta. These results suggest that $\mathrm{IL}$ 6 may also be involved in the production and release of GEL.

Attempts ${ }^{9,20-22}$ have been made to explain ischaemic

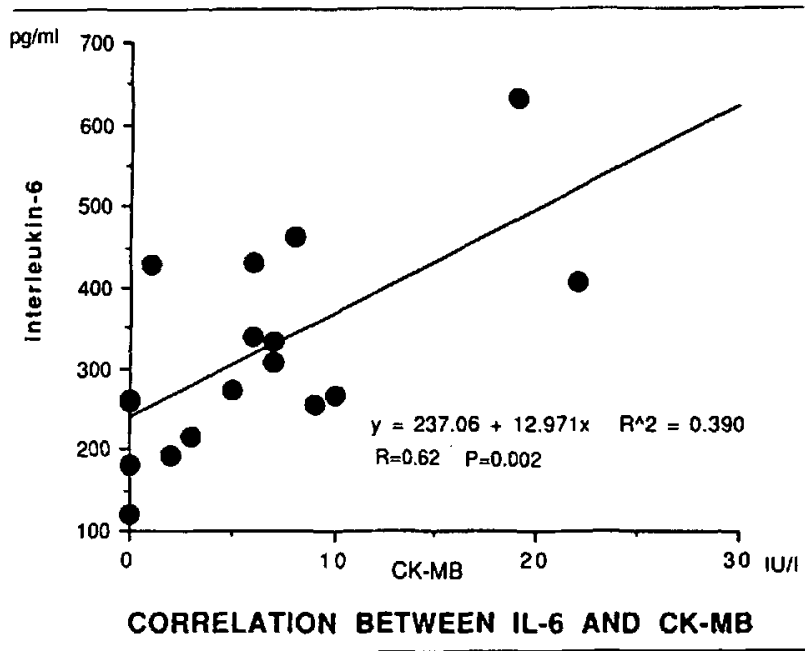

FIGURE 8 Relationship between absolute values in interleukin 6 and $\mathrm{CK}-\mathrm{MB}(\mathrm{R}=0.62, P=0.002)$.

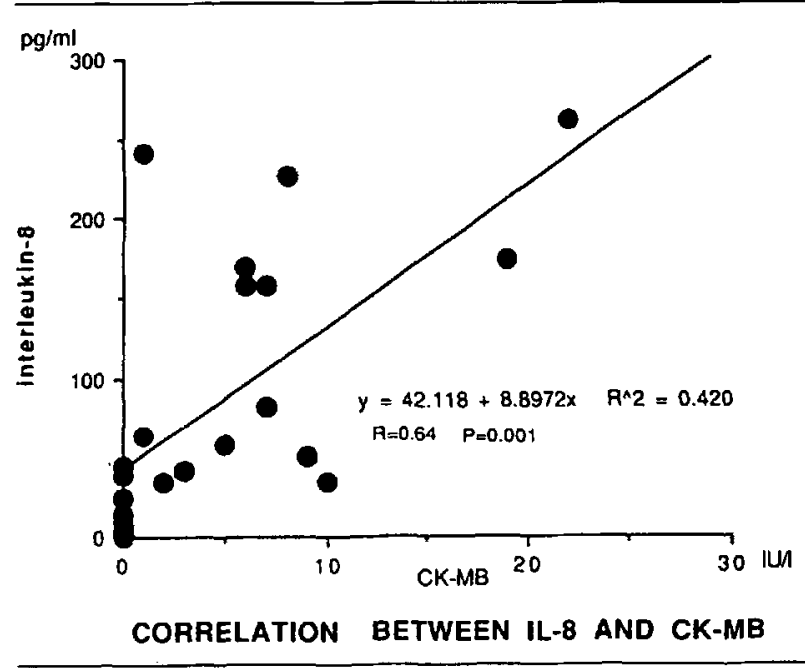

FIGURE 9 Relationship between absolute values in interleukin 8 and CK-MB $(\mathrm{R}=0.64, P=0.001)$.

myocardial injury associated with neutrophils by (1) oxygen free radicals, (2) metabolites of arachidonic acid produced by the lipoxygenase pathway, and (3) neutrophil lysozomes including GEL. These substances appear only after activation of neutrophils, therefore there is a strong possibility that reperfusion injury might be controlled if IL-6, IL-8 and other substances which activate neutrophils are inhibited. The results of our study seem to support this possibility. Glucocorticoid, ${ }^{23}$ and IL $-4{ }^{24}$ suppress the production of IL- 8 . If these substances are used in open heart surgery with cardiopulmonary bypass, myocardial injury might be relieved.

In conclusion, the possibility of the participation of cytokines and neutrophils in reperfusion injury was in- 
vestigated in 11 patients with CPB. Sixty minutes after declamping of the aorta, CK, CK-MB, neutrophils and GEL began to increase suggesting that neutrophils might participate in reperfusion injury. At the same time IL6 and IL- 8 concentrations began to increase. IL-8 was positively correlated with GEL, indicating that it was involved in cell injury following neutrophil activation.

\section{References}

1 Romson JL, Hook BG, Kunkel SL, Abrams GD, Schork $M A$, Lucchesi $B R$. Reduction of the extent of ischemic myocardial injury by neutrophil depletion in the dog. Circulation 1983; 67: 1016-23.

2 Mullane KM, Read N, Salmon JA, Moncada S. Role of leukocytes in acute myocardial infarction in anesthetized dogs: relationship to myocardial salvage by antiinflammatory drugs. J Pharmacol Exp Ther 1984; 228: 510-22.

3 Ida $N$, Sakurai $S$, Hosoi K, Kunitomo T. A highly sensitive enzyme-linked immunosorbent assay for the measurement of interleukin-8 in biological fluids. J Immunol Methods 1992; 156: 27-38.

4 Ida N, Sakurai $S$, Hosaka T, et al. An enzyme-linked immunosorbent assay for the measurement of human interleukin-6. J Immunol Methods 1990; 133: 279-84.

5 Mullane KM, Moncada $S$. The salvage of ischemic myocardium by BW $755 \mathrm{C}$ in anaesthetized dogs. Prostaglandins 1982; 24: 255-66.

6 Lawrence $M B$, Springer TA. Leukocytes roll on a selection at physiologic flow rates: distinction from and prerequisite for adhesion through integrins. Cell 1991; 65: 859-73.

7 Shröder JM, Mrowietz U, Morita E, Christophers E. Purification and partial biochemical characterization of a human monocyte-derived, neutrophil-activating peptide that lacks interleukin 1 activity. J Immunol 1987; 139: 3474-83.

8 Peveri P, Walz A, Dewald B, Baggiolini M. A novel neutrophil-activating factor produced by human mononuclear phagocytes. J Exp Med 1988; 167: 1547-59.

9 Schröder $J M$. The monocyte-derived neutrophil activating peptide (NAP/interleukin 8) stimulates human neutrophil archidonate-5-lipoxygenase, but not the release of cellular arachidonate. J Exp Med 1989; 170: 847-63.

10 Paccaud JP, Shifferli JA, Baggiolini $M$. NAP-1/IL-8 induces up-regulation of CRI receptors in human neutrophil leukocytes. Biochem Biophys Res Comm 1990; 166: 187-92.

11 Detmers PA, Lo SK, Olsen-Egbert E, Walz A, Baggiolini $M$, Cohn $Z A$. Neutrophil-activating protein 1/ interleukine- 8 stimulates the binding activity of the leukocyte adhesion receptor CD11b/CD18 on human neutrophils. J Exp Med 1990; 171: 1155-62.

12 Endo S, Inada S, Yamashita N, Hoshi S, Yoshida M, Ceska $M$. Polymorphonuclear leukocyte elastase and plasma interleuken 8 levels in patients with ARDS. Journal of the Japanese Association for Acute Medicine. 1992; 3: 92.

13 Matsushima K, Morishita K, Yoshimura T, et al. Molecular cloning of a human monocyte-derived neutrophil chemotactic factor (MDNCF) and the induction of MDNCF mRNA by interleukin 1 and tumor necrosis factor. J Exp Med 1988; 167: 1883-93.

14 Larsen CG, Anderson AP, Oppenheim JJ, Matsushima K. Production of interleukin- 8 by human dermal fibroblasts and keratinocytes in response to interleukin-l or tumor necrosis factor. Immunology 1989; 68: 31-6.

15 Strieter RM, Kunkel SL, Showell HJ, et al. Endothelial cell gene expression of a neutrophil chemotactic factor by TNF- $\alpha$, LPS, and IL-1 $\beta$. Science 1989; 243: 1467-9.

16 Metinko A, Kunkel S, Standiford T, Streter $R$. Monocyte expression of interleukin-8 in response to oxidant stress. FASEB J abstracts part 1 1991: 1941 A704.

17 Horii Y, Muraguchi A, Suematsu S, et al. Regulation of BSF-2/IL-6 production by human mononuclear cells: macrophage-dependent synthesis of BSF-2/IL- 6 by T cells. J Immunol 1988; 141: 1529-35.

18 Matsuzaki N, Saji F, Kameda T, et al. In vitro and in vivo production of interleukin- 6 by fetal mononuclear cells. Clin Immunol Immunopathol 1990; 55: 305-14.

19 Hirano T, Kishimoto T. Interleukin 6. In: Sporn MB, Roberts AB (Eds.). Handbook of Experimental Pharmacology vol. 95/1 "Peptide Growth Factors and Their Receptors." Berlin: Springer-Verlag 1990; 633-65.

20 Weiss SJ, Curnutte JT, Regiani S. Neutrophil-mediated solubilization of the subendothelial matrix: oxidative and nonoxidative mechanisms of proteolysis used by normal and chronic granulomatous disease phagocytes. J Immunol 1986; 136: 636-41.

21 Kusner DJ, King CH. Protease-modulation of neutrophil superoxide response. J Immunol 1989; 143: 1696-702.

22 Peveri $P$, Walz $A$, Dewald B, Baggiolini $M$. A novel neutrophil-activating factor produced by human mononuclear phagocytes. J Exp Med 1988; 167: 1547-59.

23 Mukaida N, Shiroo M, Matsusima $K$. Genomic structure of the human monocyte-derived neutrophil chemotactic factor IL-8. J Immunol 1989; 143: 1366-71.

24 Standiford TJ, Strieter RM, Chensue SW, Westwick J, Kasahara $K$, Kunkel $S L$. IL-4 inhibits the expression of IL-8 from stimulated monocytes. J Immunol 1990; 145: 1435-9. 